\title{
CORRIGENDA
}

\section{Induction of lipogenesis in white fat during cold exposure in mice: link to lean phenotype}

P Flachs, K Adamcova, P Zouhar, C Marques, P Janovska, I Viegas, JG Jones, K Bardova, M Svobodova, J Hansikova, O Kuda, M Rossmeisl, U Liisberg, AG Borkowska, K Kristiansen, L Madsen and J Kopecky

International Journal of Obesity (2017) 41, 997; doi:10.1038/ijo.2017.61

Correction to: International Journal of Obesity advance online publication 17 January 2017; doi:10.1038/ijo.2016.228

The authors omitted the following acknowledgement from their manuscript:

This work was also supported from Fundação para a Ciência e Tecnologia (FCT) in the form of a Fellowship to I.V.: SFRH/BPD/
90032/2012, structural funding for the CNC (PEst-C/SAU/LA0001/ 2013-2014) and grant EXPL/DTP-PIC/0069/2012. NMR data was collected at the UC-NMR facility that is supported by FEDER and FCT (RECI/QEQ-QFI/0168/2012， CENTRO-07-CT62-FEDER-002012) and Rede Nacional de Ressonância Magnética Nuclear (RNRMN). EASD Albert Renold Travel Fellowship (P. Zouhar).

\section{OPEN}

Weight losses with low-energy formula diets in obese patients with and without type 2 diabetes: systematic review and meta-analysis

WS Leslie, R Taylor, L Harris and MEJ Lean

International Journal of Obesity (2017) 41, 997; doi:10.1038/ijo.2017.46; published online 14 March 2017

Correction to: International Journal of Obesity (2017) 41, 96-101; doi:10.1038/ijo.2016.175; published online 4 October 2015

Updated online 14 March 2017: This article was originally published under a standard license, but has now been made available under a CC BY-NC-ND 4.0 license. The pdf and html versions of the paper have been modified accordingly.

\begin{abstract}
(c) (i) $\odot$ This work is licensed under a Creative Commons AttributionBY NC ND NonCommercial-NoDerivs 4.0 International License. The images or other third party material in this article are included in the article's Creative Commons license, unless indicated otherwise in the credit line; if the material is not included under the Creative Commons license, users will need to obtain permission from the license holder to reproduce the material. To view a copy of this license, visit http:// creativecommons.org/licenses/by-nc-nd/4.0/
\end{abstract}

(c) The Author(s) 2017

\section{Loss of anti-contractile effect of perivascular adipose tissue in offspring of obese rats}

KE Zaborska, M Wareing, G Edwards and C Austin

International Journal of Obesity (2017) 41, 997; doi:10.1038/ijo.2017.17; published online 30 March 2017

Correction to: International Journal of Obesity (2016) 1205-1214; doi:10.1038/ijo.2016.62
40, The licence type of this article has been changed from CC-BY-ND to CC-BY since publication. 